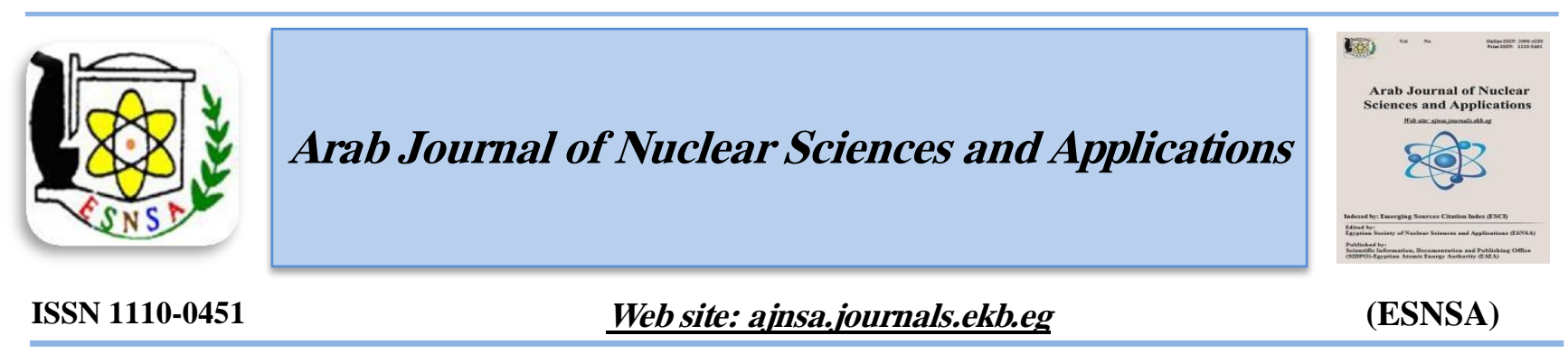

\title{
Detection of Natural Radionuclides Concentration in Corchorus Olitorius and Soil as Affected by Different Fertilizers
}

\author{
M.A. Salama, Kh.M. Yousef, A.Z. Mostafa \\ Soil and Water Research Department, Nuclear Research Center, Atomic Energy Authority, Egypt
}

Received $21^{\text {st }}$ Feb. 2018 Accepted 30 ${ }^{\text {th }}$ May 2018

\section{Introduction}

All minerals and raw materials contain radionuclides of natural origin. The most important, for the purposes of radiation protection, are the radionuclides in the ${ }^{235} \mathrm{U}\left(\mathrm{T}_{1 / 2}=7.04 \times 108 \mathrm{y}\right)$, ${ }^{238} \mathrm{U}\left(\mathrm{T}_{1 / 2}=4.47 \times 109 \mathrm{y}\right),{ }^{232} \mathrm{Th}\left(\mathrm{T}_{1 / 2}=1.4 \times 1010 \mathrm{y}\right)$ decay chains as well as singly occurring types such as ${ }^{40} \mathrm{~K}\left(\mathrm{~T}_{1 / 2}=1.28 \times 109 \mathrm{y}\right)$. The most important sources of external and internal exposure are the gamma radiation and alpha particles emitted from the radionuclides of the uranium $\left({ }^{238} \mathrm{U}\right)$ series, thorium $\left({ }^{232} \mathrm{Th}\right)$ series and ${ }^{40} \mathrm{~K}$ present within phosphate rocks. External exposure occurs directly by $\gamma$-rays, whereas internal exposure to $\alpha$-particles arises from the inhalation of radon and its progenies. Consequently, the $\alpha$-particle dose is delivered directly to the bronchial tissue, creating a potential for radiogenic lung cancer [1-2].

Radionuclides in soil are usually transferred to different plant tissues by direct transfer via the root system, or fallout of radionuclides and resuspension of contaminated soil followed by deposition on plant leaves ${ }^{[3]}$. The soil-to-plant transfer factor (TF) is regarded as one of the most important parameters used in environmental safety assessment to estimate the amount of radioactivity that could be present in agricultural crops and estimating dose impact to human body [4-5].

The direct contamination of terrestrial vegetation refers to the deposition of radioactive materials from the atmosphere onto the above ground plant parts [6]. Indirect contamination refers to the absorption of radionuclides from the soil by the root system of plants [7]. Therefore, it is necessary to determine the activity concentration of radionuclides in vegetables that are highly consumed by the Egyptians either as fresh or cooked food. Jew's-mallow is extremely a popular national Egyptian food.

The present study aims to determine the activity concentrations of radionuclides $\left({ }^{226} \mathrm{Ra},{ }^{238} \mathrm{U},{ }^{232} \mathrm{Th}\right.$

Corresponding author: mnsalama@yahoo.com

DOI: 10.21608/ajnsa.2018.2950.1063

(C) Scientific Information, Documentation and Publishing Office (SIDPO)-EAEA 
and ${ }^{40} \mathrm{~K}$ ) in Jew's-mallow plant fertilized with different fertilizers.

\section{Materials and Method}

Set-up and treatments

The pot experiment was conducted at the Farm of Soil and Water Research Department, Nuclear Research Center, Atomic Energy Authority, Inshas, Egypt. The experimental site is located at $30^{\circ} 23^{\prime} 41.26^{\prime \prime} \mathrm{N}$ latitude, $31^{\circ} 23^{\prime} 41.26^{\prime \prime} \mathrm{E}$ longitude while the altitude is $26 \mathrm{~m}$ above the sea level. Some of experimental soil properties are presented in Table (1). The physical properties were determined according to Klute[8] and chemical properties based on the method reported by Page [9]. The set-up consists of 27 pots (PE) packed with $6 \mathrm{~kg}$ of sandy loam soil.

\section{Fertilization treatments}

Eight mixed treatments of commercial fertilizers have been used in addition to unfertilized control
(T0) (Table 2) and replicated three times. Treatments were arranged as follows:

- Two types of phosphate, the first one (F1) is calcium super phosphate $\left(\mathrm{H}_{6} \mathrm{CaO}_{9} \mathrm{P}_{2}\right)$ $(15 \% \mathrm{P})$ was added at a rate of $125 \mathrm{~kg} \mathrm{ha}^{-1}$ before planting and the second one (F2) is phosphoric acid $\left(\mathrm{H}_{3} \mathrm{PO}_{4}\right)(85 \%)$ was added at a rate of $30 \mathrm{~kg} \mathrm{P} \mathrm{ha}^{-1}$ after 20 days from planting date.

- Two types of nitrogen, the first one (F3) is ammonium sulphate $\left(\left(\mathrm{NH}_{4}\right)_{2} \mathrm{SO}_{4}\right) \quad(20.6 \%$ $\mathrm{N})$ was added at a rate of $250 \mathrm{~kg} \mathrm{ha}^{-1}$ and the second one (F4) is urea $\left(\mathrm{NH}_{2} \mathrm{CONH}_{2}\right)$ $(46 \% \mathrm{~N})$ was added at a rate of $120 \mathrm{~kg} \mathrm{ha}^{-}$ 1 , and

- Two types of potassium F5, F6 potassium sulphate $\left(\mathrm{K}_{2} \mathrm{SO}_{4}\right)(48 \% \mathrm{~K})$, the first one (F5) is Belgian potassium sulphate and the second one (F6) is Egyptian potassium sulphate were added at a rate of $65 \mathrm{~kg} \mathrm{ha}^{-1}$.

Table (1): Some physical and chemical parameters of experimental soil

\begin{tabular}{ll}
\hline Parameter & Character/value \\
\hline Texture & Sandy loam \\
Clay & $7.5 \%$ \\
Sand & $65.2 \%$ \\
Silt & $27.3 \%$ \\
Field capacity, $\theta_{\mathrm{FC}}$ & $17.33 \%$ \\
Wilting point, $\theta_{\mathrm{WP}}$ & $9.62 \%$ \\
$\mathrm{pH}^{-}$ & 8.17 \\
$\mathrm{EC}_{\mathrm{e}}($ Electrical conductivity) & $0.56 \mathrm{dS} \mathrm{m}^{-1}$ \\
$\mathrm{Na}^{+}$ & $1.41 \mathrm{meq} \mathrm{l}^{-1}$ \\
$\mathrm{~K}^{+}$ & $0.22 \mathrm{meq} \mathrm{l}^{-1}$ \\
$\mathrm{Ca}^{++}$ & $2.80 \mathrm{meq} \mathrm{l}^{-1}$ \\
$\mathrm{Mg}^{++}$ & $1.13 \mathrm{meq} \mathrm{l}^{-1}$ \\
$\mathrm{CO}_{3}^{--}$ & - \\
$\mathrm{HCO}_{3}^{-}$ & $2.56 \mathrm{meq} \mathrm{l}^{-1}$ \\
$\mathrm{CL}^{-}$ & $2.20 \mathrm{meq} \mathrm{l}^{-1}$ \\
$\mathrm{SO}_{4}^{--}$ & $0.80 \mathrm{meq} \mathrm{l}^{-1}$ \\
\hline
\end{tabular}


Table (2): Description of fertilization treatments

\begin{tabular}{ccc}
\hline Treatments & Fertilizer added to soil & Composition \\
\hline \multicolumn{3}{c}{ Non-fertilizer } \\
\hline T0 & \multicolumn{2}{c}{ Fertilizer } \\
\hline T1 & F1 + F6 + F3 & $\left(\mathrm{H}_{6} \mathrm{CaO}_{9} \mathrm{P}_{2}\right)+\left(\mathrm{K}_{2} \mathrm{TO}_{4}\right)($ Egyptian $\left.)+\left(\mathrm{NH}_{4}\right)_{2} \mathrm{SO}_{4}\right)$ \\
T2 & $\mathrm{F} 1+\mathrm{F} 6+\mathrm{F} 4$ & $\left(\mathrm{H}_{6} \mathrm{CaO}_{9} \mathrm{P}_{2}\right)+\left(\mathrm{K}_{2} \mathrm{SO}_{4}\right)($ Egyptian $)+\left(\mathrm{NH}_{2} \mathrm{CONH}_{2}\right)$ \\
T3 & $\mathrm{F} 1+\mathrm{F} 5+\mathrm{F} 3$ & $\left(\mathrm{H}_{6} \mathrm{CaO}_{9} \mathrm{P}_{2}\right)+\left(\mathrm{K}_{2} \mathrm{SO}_{4}\right)($ Belgian $\left.)+\left(\mathrm{NH}_{4}\right)_{2} \mathrm{SO}_{4}\right)$ \\
T4 & $\mathrm{F} 1+\mathrm{F} 5+\mathrm{F} 4$ & $\left(\mathrm{H}_{6} \mathrm{CaO}_{9} \mathrm{P}_{2}\right)+\left(\mathrm{K}_{2} \mathrm{SO}_{4}\right)($ Belgian $)+\left(\mathrm{NH}_{2} \mathrm{CONH}_{2}\right)$ \\
T5 & $\mathrm{F} 2+\mathrm{F} 6+\mathrm{F} 3$ & $\left(\mathrm{H}_{3} \mathrm{PO}_{4}\right)+\left(\mathrm{K}_{2} \mathrm{SO}_{4}\right)($ Egyptian $\left.)+\left(\mathrm{NH}_{4}\right)_{2} \mathrm{SO}_{4}\right)$ \\
T6 & $\mathrm{F} 2+\mathrm{F} 6+\mathrm{F} 4$ & $\left(\mathrm{H}_{3} \mathrm{PO}_{4}\right)+\left(\mathrm{K}_{2} \mathrm{SO}_{4}\right)($ Egyptian $)+\left(\mathrm{NH}_{2} \mathrm{CONH}_{2}\right)$ \\
T7 & $\mathrm{F} 2+\mathrm{F} 5+\mathrm{F} 3$ & $\left(\mathrm{H}_{3} \mathrm{PO}_{4}\right)+\left(\mathrm{K}_{2} \mathrm{SO}_{4}\right)($ Belgian$\left.)+\left(\mathrm{NH}_{4}\right)_{2} \mathrm{SO}_{4}\right)$ \\
T8 & $\mathrm{F} 2+\mathrm{F} 5+\mathrm{F} 4$ & $\left(\mathrm{H}_{3} \mathrm{PO}_{4}\right)+\left(\mathrm{K}_{2} \mathrm{SO}_{4}\right)($ Belgian$)+\left(\mathrm{NH}_{2} \mathrm{CONH}_{2}\right)$ \\
\hline
\end{tabular}

\section{Cultivated crop and irrigation}

The cultivated plant is Jew's-mallow (Corchorus olitorius) variety Eskandarany provided by the Agriculture Research Center, Cairo, Egypt. The experiment started on April 1, 2015 and harvested at June 8,2015 . The amount of seeds required was $15 \mathrm{~kg}$ seeds ha ${ }^{-1}$. All pots were kept at same open environmental condition (open-door experiment). After 69 days from planting date, plants were collected.

Irrigation water was applied based on the gravimetric method. Determination of the initial soil moisture and field capacity were done to compensate the loss of water by evapotranspiration. Gravimetric (weight-based) methods that rely on measuring the loss of water from the containers are common techniques for determining when and how much to irrigate [1011- 12].

\section{Experimental methods}

Sample preparation

Soil samples were air dried. For maximum moisture removal, all samples were then dried at $110{ }^{\circ} \mathrm{C}$ in a microprocessor-controlled furnace for about $24 \mathrm{~h}$. The fertilizers samples were crushed to fine powder forms and sieved through a $1 \mathrm{~mm}$ mesh size to remove the larger grain sizes and making them more homogenous. Then, the samples were dried in a temperature controlled furnace at $110{ }^{\circ} \mathrm{C}$ for $24 \mathrm{~h}$ to ensure that moisture was completely removed. Jew's-mallow samples were washed, peeled when necessary, and dried in air. After that, they were oven dried at $80{ }^{\circ} \mathrm{C}$ for approximately $16 \mathrm{~h}[13]$.

The dried samples of soil, fertilizer and Jew'smallow were packed and sealed in plastic containers, i.e., normal cylindrical plastic containers $(6 \mathrm{~cm}$ diameter and $8 \mathrm{~cm}$ height) made from polyethylene. Then the samples were left for 4 weeks before the measurements in order to get the secular equilibrium to achieve radioactive secular equilibrium between radioactive materials and daughter nuclei [14].

\section{Radioactivity measurements}

The activity concentration of natural radionuclides in soil, fertilizers and Jew's mallow were measured in the laboratories of Department of Radiation Protection and Civil Defense, Nuclear Research Center, Atomic Energy Authority, Egypt using high purity germanium (HPGe) semiconductor detector, type CANBERRA (HPGe) detector of relative efficiency $50 \%$ coupled to a 4096 channel analyzer. The outstanding advantage of the HPGe detector is its ability to measure gamma radiation directly from the original sample without the need for chemical separation and high resolving power.

\section{Transfer factors}

Radionuclides in soils are usually transferred to different plant tissues by direct transfer via the root system, as well as radionuclide fallout and resuspension of contaminated soil followed by deposition on plant leaves [15]. In Equation (1) the transfer factor (TF) values are calculated according to the following equation: 
$T F=\frac{\text { Activity of radionuclides in plant weight }(\mathrm{Bq} / \mathrm{Kg} \text { dry weight })}{\text { Activity of radionuclides in soil weight }(\mathrm{Bq} / \mathrm{Kg} \text { dry weight })}$

\section{Effective dose due to ingestion}

Effective dose in food stuffs is a useful concept that enables the radiation doses from different radionuclides and sources of radioactivity to be added [16]. When analyzing the total annual effective dose (AED) to the human population from natural sources, the dose received by ingestion of long-lived natural radionuclides must be considered. Effective doses resulting from the intake of ${ }^{226} \mathrm{Ra},{ }^{238} \mathrm{U},{ }^{232} \mathrm{Th}$ and ${ }^{40} \mathrm{~K}$, may be determined directly from external measurements of their concentrations in the body or estimated from intake concentrations of materials such as air, food and water. Radiation doses ingested are obtained by measuring radionuclide activity in foodstuffs $\left(\mathrm{Bq} \mathrm{kg}^{-1}\right)$ and multiplying these by the masses of food consumed over a period of time $\left(\mathrm{kg} \mathrm{d}^{-1}\right.$ or $\mathrm{kg}$ $\left.\mathrm{yr}^{-1}\right)$. A dose conversion factor $\left(\mathrm{Sv} \mathrm{Bq}{ }^{-1}\right)$ can then be applied to give an estimate of ingestion dose. Thus, the effective dose $E\left(\mathrm{~Sv} \mathrm{yr}{ }^{-1}\right)$ due to intake of a radionuclide with the ingested material is calculated using the following Equation (2) [17]:

$$
E=C \sum A_{i} D C F_{i}
$$

\section{Where:}

$E \quad:$ The effective dose due to ingestion of natural radionuclide $\left(\mathrm{Sv} \mathrm{yr}^{-1}\right)$,

$C \quad$ : Mean annual consumption of foodstuff $\left(\mathrm{kg} \mathrm{yr}^{-1}\right)$,

$A_{i} \quad$ : Activity concentration of radionuclide $i$ in the ingested material $\left(\mathrm{Bq} \mathrm{kg}^{-1}\right)$, and

$D C F_{i} \quad$ : The standard dose conversion factor $(\mathrm{Sv}$ $\left.\mathrm{Bq}^{-1}\right)$, which is equal to $2.8 \times 10^{-7} \mathrm{~Sv} \mathrm{~Bq}^{-1}$ for ${ }^{226} \mathrm{Ra}, 2.2 \times 10^{-7} \mathrm{~Sv} \mathrm{~Bq}^{-1}$ for ${ }^{232} \mathrm{Th}, 6.2 \times 10^{-9} \mathrm{~Sv} \mathrm{~Bq}$ ${ }^{1}$ for ${ }^{40} \mathrm{~K}$ and $4.4 \times 10^{-8} \mathrm{~Sv} \mathrm{~Bq}^{-1}$ for ${ }^{238} \mathrm{U}^{[18-19]}$.

\section{Excess lifetime cancer risk}

Excess Lifetime Cancer Risk (ELCR) can be defined as the excess probability of developing cancer at a lifetime due to exposure level of human to radiation. Excess Lifetime Cancer Risk (ELCR) was calculated by using the following Equation (3) [20-21-22]:

$$
E L C R=E \times D_{L} \times R_{F}
$$

Where $E$ is the effective dose due to ingestion of natural radionuclide $\left(\mathrm{Sv} \mathrm{yr}^{-1}\right), D_{L}$ is duration of life (approximately 70 year) and $R_{F}$ is risk factor $\left(\mathrm{Sv}^{-1}\right)$ fatal cancer risk per Sievert. For stochastic effects, ICRP 60 uses values of $\left(R_{F}=0.05\right)$ for public. The worldwide recommended value is $0.29 \times 10^{-3}[23]$.

\section{Results}

Concentrations of natural radionuclides in fertilizer

The measured concentrations of natural radionuclides ${ }^{226} \mathrm{Ra},{ }^{238} \mathrm{U},{ }^{232} \mathrm{Th}$ and ${ }^{40} \mathrm{~K}$ in fertilizer samples are presented in Table (3). In chemical fertilizers, the concentration of ${ }^{226} \mathrm{Ra}$ varies from $\mathrm{ND}$ (not detection) to $1121 \mathrm{~Bq} \mathrm{~kg}{ }^{-1}$ with an average value of $198.10 \mathrm{~Bq} \mathrm{~kg}^{-1}$, the concentration of ${ }^{238} \mathrm{U}$ varies from ND to $720 \mathrm{~Bq} \mathrm{~kg}{ }^{-1}$ with an average value of $121.87 \mathrm{~Bq} \mathrm{~kg}^{-1}$, the concentration of ${ }^{232} \mathrm{Th}$ varies from ND to $6.8 \mathrm{~Bq} \mathrm{~kg}^{-1}$ with an average value of $2.47 \mathrm{~Bq} \mathrm{~kg}{ }^{-1}$, whereas the concentration of ${ }^{40} \mathrm{~K}$ exists in the range from ND$248.36 \mathrm{~Bq} \mathrm{~kg}^{-1}$ with an average value of $62.1 \mathrm{~Bq}$ $\mathrm{kg}^{-1}$. For F1, F2, F3, F4, F5 and F6 fertilizer, the average activity of all natural radionuclides $\left({ }^{226} \mathrm{Ra}\right.$, ${ }^{238} \mathrm{U},{ }^{232} \mathrm{Th}$ and ${ }^{40} \mathrm{~K}$ ) were $460.25,16.70,4.93$, $20.15,62.09$ and $12.68 \mathrm{~Bq} \mathrm{~kg}^{-1}$, respectively. In comparison with reference value, NPK fertilizers added at F5 treatment emitted the highest radiation while other treatments were less.

Concentration of natural radionuclide in soil The values of specific activity for ${ }^{226} \mathrm{Ra},{ }^{238} \mathrm{U},{ }^{232} \mathrm{Th}$ and ${ }^{40} \mathrm{~K} \mathrm{~Bq} \mathrm{~kg}^{-1}$ of the studied soil samples before sowing and after harvesting are illustrated in Table (4). The average ${ }^{238} \mathrm{U}$ and ${ }^{232} \mathrm{Th}$ activities in the soil samples were lower than the worldwide average depending on geologic structure of the region. ${ }^{226} \mathrm{Ra}$ and ${ }^{40} \mathrm{~K}$ activity level in soil sample was slightly higher than worldwide average in T6 for ${ }^{226} \mathrm{R}$ and $\mathrm{T} 8$ for ${ }^{40} \mathrm{~K}$, while all other treatments indicated that the value of ${ }^{226} \mathrm{Ra}$ and ${ }^{40} \mathrm{~K}$ was lower than the worldwide average. A comparison held between the beginning and end of growing seasons showed that the fertilized soil contains slightly higher concentrations of natural radionuclides than the non-fertilized soil, but is still in the recommended value except $\mathrm{T} 6$ [fertilized by phosphoric acid $\left(\mathrm{H}_{3} \mathrm{PO}_{4}\right)$, urea $\mathrm{CO}\left(\mathrm{NH}_{2}\right)_{2}$ and potassium sulphate $\mathrm{K}_{2} \mathrm{SO}_{4}$ (Egypt)] which contain high concentration of ${ }^{226} \mathrm{Ra}$ and for T8 [fertilized by phosphoric acid $\left(\mathrm{H}_{3} \mathrm{PO}_{4}\right)$, ammonium sulphate $\left(\mathrm{NH}_{4}\right)_{2} \mathrm{SO}_{4}$, and potassium sulphate $\mathrm{K}_{2} \mathrm{SO}_{4}$ (Belgian)] which contain slight high concentration of ${ }^{40} \mathrm{~K}$. 
Table (3): The activity concentrations of ${ }^{226} \mathrm{Ra},{ }^{238} \mathrm{U},{ }^{232} \mathrm{Th}$ and ${ }^{40} \mathrm{~K}\left(\mathrm{~Bq} \mathrm{~kg}{ }^{-1}\right)$ in chemical fertilizers

\begin{tabular}{cccccc}
\hline $\begin{array}{c}\text { Chemical } \\
\text { fertilizers }\end{array}$ & $\begin{array}{c}{ }^{226} \mathrm{Ra} \\
\mathrm{Bq} \mathrm{kg}^{-1}\end{array}$ & $\begin{array}{c}{ }^{238} \mathrm{U} \\
\mathrm{Bq} \mathrm{kg}^{-1}\end{array}$ & $\begin{array}{c}{ }^{232} \mathrm{Th} \\
\mathrm{Bq} \mathrm{kg}^{-1}\end{array}$ & $\begin{array}{c}{ }^{40} \mathrm{~K} \\
\mathrm{~Bq} \mathrm{~kg}^{-1}\end{array}$ & $\begin{array}{c}\text { Average } \\
\mathrm{Bq} \mathrm{kg}^{-1}\end{array}$ \\
\hline $\mathrm{F} 1$ & $1121 \pm 10$ & $720 \pm 7$ & $\mathrm{ND}$ & $\mathrm{ND}$ & 460.25 \\
$\mathrm{~F} 2$ & $11 \pm 1$ & $2.9 \pm 2$ & $3.9 \pm 2.5$ & $49 \pm 3$ & 16.70 \\
F3 & $7.2 \pm 0.6$ & $3 \pm 0.4$ & $1.5 \pm 0.6$ & $8 \pm 1$ & 4.93 \\
F4 & $40 \pm 3$ & $2.8 \pm 1.2$ & $6.8 \pm 2$ & $31 \pm 2$ & 20.15 \\
F5 & $\mathrm{ND}$ & $\mathrm{ND}$ & $\mathrm{ND}$ & $248.36 \pm 20$ & 62.09 \\
F6 & $9.4 \pm 2$ & $2.5 \pm 0.5$ & $2.6 \pm 1$ & $36.2 \pm 3$ & 12.68 \\
\hline Average & $198.10 \pm 2.8$ & $121.87 \pm 1.85$ & $2.47 \pm 1.02$ & $62.1 \pm 4.8$ & $62.1 \pm 10.47$ \\
Range & $7.2-1121$ & $2.5-720$ & $1.5-6.8$ & $8-248.36$ & $4.93-460.25$
\end{tabular}

ND: Not detected

Table (4): The average value of specific activity of ${ }^{226} \mathrm{Ra},{ }^{238} \mathrm{U},{ }^{232} \mathrm{Th}$ and ${ }^{40} \mathrm{~K}$ in Bq $\mathrm{kg}^{-1}$ of studied soil samples without fertilized (T0) and after fertilized (T1-T8)

\begin{tabular}{|c|c|c|c|c|}
\hline Treatments & $\begin{array}{c}{ }^{226} \mathrm{Ra} \\
\mathrm{Bq} \mathrm{kg}^{-1}\end{array}$ & $\begin{array}{c}{ }^{238} \mathrm{U} \\
\mathbf{B q} \mathbf{k g}^{-1}\end{array}$ & $\begin{array}{c}{ }^{232} \mathrm{Th} \\
\mathrm{Bq} \mathrm{kg}^{-1}\end{array}$ & $\begin{array}{c}{ }^{40} \mathrm{~K} \\
\mathrm{~Bq} \mathrm{~kg}^{-1}\end{array}$ \\
\hline \multicolumn{5}{|c|}{ Non-fertilizer } \\
\hline T0 & $18 \pm 1.1$ & $13 \pm 1$ & $20.2 \pm 1.9$ & $304 \pm 3$ \\
\hline \multicolumn{5}{|c|}{ Fertilizer } \\
\hline $\mathbf{T 1}$ & $22 \pm 1.8$ & $13 \pm 0.9$ & $18.5 \pm 1$ & $325 \pm 3$ \\
\hline T2 & $22 \pm 1.9$ & $10.1 \pm 1$ & $20.1 \pm 1.8$ & $293 \pm 2.9$ \\
\hline $\mathbf{T 3}$ & $31.5 \pm 3$ & $15 \pm 1.2$ & $25.2 \pm 1.9$ & $367 \pm 3.6$ \\
\hline T4 & $28.1 \pm 2.1$ & $14.6 \pm 1.2$ & $20.2 \pm 1.9$ & $374 \pm 3.7$ \\
\hline T5 & $24 \pm 2$ & $12.1 \pm 1.2$ & $23.2 \pm 1.3$ & $330 \pm 3$ \\
\hline T6 & $72.2 \pm 7$ & $15 \pm 1.1$ & $20.2 \pm 1.9$ & $338 \pm 3$ \\
\hline $\mathbf{T 7}$ & $27.3 \pm 2$ & $14 \pm 1.4$ & $24 \pm 2.1$ & $379 \pm 3.7$ \\
\hline T8 & $25.6 \pm 2$ & $12.1 \pm 1.2$ & $20 \pm 1.8$ & $422 \pm 4$ \\
\hline Average & $31.59 \pm 2.73$ & $13.23 \pm 1.15$ & $21.43 \pm 1.48$ & $353.5 \pm 3.36$ \\
\hline Range & $22-72$ & $10-15$ & $18-25.2$ & 293-422 \\
\hline Worldwide & 32 & 33 & 45 & 420 \\
\hline
\end{tabular}


Concentration of natural radionuclides in Jew'smallow plant

The activity concentration of ${ }^{226} \mathrm{Ra},{ }^{238} \mathrm{U},{ }^{232} \mathrm{Th}$ and ${ }^{40} \mathrm{~K}$ in $\mathrm{Bq} \mathrm{kg}{ }^{-1}$ of Jew's-mallow plants fertilized with different fertilizers varied from 0.35-0.77, $0.016-0.1,0.09-0.22$ and $8.52-16.34 \mathrm{~Bq} \mathrm{~kg}{ }^{-1}$, respectively Table (5). High activity concentration of ${ }^{226} \mathrm{Ra},{ }^{238} \mathrm{U},{ }^{232} \mathrm{Th}$ and ${ }^{40} \mathrm{~K}$ in $\mathrm{Bq} \mathrm{kg}{ }^{-1}$ were recorded with $\mathrm{T} 2, \mathrm{~T} 1, \mathrm{~T} 2, \mathrm{~T} 2$ treatments, respectively.
Transfer factor $(T F){ }^{40} \mathrm{~K}$ has the highest values compared to other radionuclides with an average 0.0334 and ranged from 0.0202 to 0.0504 Table (6). The average concentration values of ${ }^{226} \mathrm{Ra}$, ${ }^{238} \mathrm{U}$ and ${ }^{232} \mathrm{Th}$ in Jew's-mallow were $0.018,0.0042$ and 0.0065 , respectively, and having following order ${ }^{40} \mathrm{~K}>{ }^{226} \mathrm{Ra}>{ }^{232} \mathrm{Th}>{ }^{238} \mathrm{U}$.

\begin{tabular}{|c|c|c|c|c|}
\hline \multirow[t]{2}{*}{ Treatments } & ${ }^{226} \mathrm{Ra}$ & ${ }^{238} \mathbf{U}$ & ${ }^{232} \mathrm{Th}$ & ${ }^{40} \mathrm{~K}$ \\
\hline & $B q \mathrm{~kg}^{-1}$ & $B q \mathrm{~kg}^{-1}$ & $\mathrm{~Bq} \mathrm{~kg}^{-1}$ & $\mathbf{B q ~ k g ^ { - 1 }}$ \\
\hline \multicolumn{5}{|c|}{ Non-Fertilized } \\
\hline T0 & $0.29 \pm 0.003$ & $0.05 \pm 0.01$ & $0.13 \pm 0.01$ & $9.83 \pm 0.1$ \\
\hline \multicolumn{5}{|c|}{ Fertilized } \\
\hline T1 & $0.49 \pm 0.004$ & $0.1 \pm 0.01$ & $0.13 \pm 0.02$ & $14.04 \pm 0.4$ \\
\hline $\mathbf{T} 2$ & $0.77 \pm 0.04$ & $0.06 \pm 0.005$ & $0.22 \pm 0.007$ & $14.78 \pm 0.3$ \\
\hline T3 & $0.35 \pm 0.05$ & $0.043 \pm 0.008$ & $0.13 \pm 0.001$ & $9.2 \pm 0.4$ \\
\hline T4 & $0.7 \pm 0.004$ & $0.06 \pm 0.001$ & $0.14 \pm 0.01$ & ND \\
\hline T5 & $0.09 \pm 0.006$ & $0.05 \pm 0.002$ & $0.09 \pm 0.02$ & $13.6 \pm 0.7$ \\
\hline T6 & $0.43 \pm 0.03$ & $0.03 \pm 0.009$ & $0.12 \pm 0.02$ & $15.01 \pm 0.3$ \\
\hline T7 & $0.73 \pm 0.05$ & $0.08 \pm 0.001$ & $0.15 \pm 0.09$ & $16.34 \pm 0.5$ \\
\hline T8 & $0.45 \pm 0.05$ & $0.016 \pm 0.001$ & $0.11 \pm 1.7$ & $8.52 \pm 0.8$ \\
\hline Average & $0.501 \pm 0.029$ & $0.055 \pm 0.0046$ & $0.136 \pm 0.235$ & $11.436 \pm 0.425$ \\
\hline Range & $0.35-0.77$ & $0.016-0.1$ & $0.09-0.22$ & $8.52-16.34$ \\
\hline Worldwide & 0.05 & 0.02 & 0.015 & 420 \\
\hline
\end{tabular}


Annual effective dose due to ingestion of Jew'smallow plants

The amount of fresh Jew's-mallow consumed by an adult Egyptian person in one year is $60 \mathrm{~kg}$ approximately [23]. The average annual effective dose due to ingestion Jew's-mallow from naturally occurring radioisotopes ${ }^{226} \mathrm{Ra},{ }^{238} \mathrm{U},{ }^{232} \mathrm{Th}$ and ${ }^{40} \mathrm{~K}$ is $8.421,0.144,1.80$ and $4.86 \mu \mathrm{Sv} \mathrm{y}^{-1}$ and ranged from 1.512-12.94, 0.042-0.26, 1.19-2.90 and 3.17$6.08 \mu \mathrm{Sv} \mathrm{y}^{-1}$, respectively Table (7). Also, the highest annual effective dose due to ingestion of Jew's-mallow was obtained from $\mathrm{T} 2\left(21.5 \mu \mathrm{Sv} \mathrm{y}^{-1}\right)$ which contain the highest activity concentration of
${ }^{226} \mathrm{Ra}$ and ${ }^{232} \mathrm{Th}$, while the lowest annual effective dose due to ingestion of Jew's-mallow appears in T5 $\left(7.89 \mu \mathrm{Sv} \mathrm{y}^{-1}\right)$.

Excess lifetime cancer risk form Jew's-mallow As seen in Table (8), the range of all ELCR values is between $0.025 \times 10^{-3}-0.069 \times 10^{-3}$. The calculated average value of ELCR for all samples is lower than the world average of $0.29 \times 10^{-3}{ }^{[24]}$. Thus, indication of the possibility of developing cancer cases among individuals can be neglected.

Table (6): Transfer factor for ${ }^{226} \mathrm{Ra},{ }^{238} \mathrm{U},{ }^{230} \mathrm{Th}$ and ${ }^{40} \mathrm{~K}$ from soil to Jew's-mallow plants

\begin{tabular}{|c|c|c|c|c|}
\hline Treatments & ${ }^{226} \mathbf{R a}$ & ${ }^{238} \mathbf{U}$ & ${ }^{232} \mathrm{Th}$ & ${ }^{40} K$ \\
\hline \multicolumn{5}{|c|}{ Non-Fertilized } \\
\hline T0 & 0.016 & 0.0038 & 0.0064 & 0.032 \\
\hline \multicolumn{5}{|c|}{ Fertilized } \\
\hline T1 & 0.022 & 0.0077 & 0.0070 & 0.0432 \\
\hline $\mathbf{T} 2$ & 0.035 & 0.0059 & 0.0110 & 0.0504 \\
\hline T3 & 0.011 & 0.0029 & 0.0052 & 0.0251 \\
\hline T4 & 0.025 & 0.0041 & 0.0069 & - \\
\hline T5 & 0.004 & 0.0041 & 0.0039 & 0.0412 \\
\hline T6 & 0.006 & 0.0020 & 0.0059 & 0.044 \\
\hline $\mathbf{T 7}$ & 0.027 & 0.0057 & 0.0063 & 0.0431 \\
\hline T8 & 0.014 & 0.0013 & 0.0055 & 0.0202 \\
\hline Average & 0.018 & 0.0042 & 0.0065 & 0.0334 \\
\hline Range & 0.004-0.035 & 0.0013-0.0077 & 0.0039-0.0110 & 0.0202-0.0504 \\
\hline
\end{tabular}


Table (7): Annual effective dose due to ingestion of Jew's-mallow plants $\left(\mu \mathrm{Sv} \mathrm{y}^{-1}\right)$

\begin{tabular}{|c|c|c|c|c|c|}
\hline Treatments & $\begin{array}{c}{ }^{226} \mathrm{Ra} \\
\mu \mathrm{Sv} \mathrm{y}^{-1}\end{array}$ & $\begin{array}{c}{ }^{238} \mathrm{U} \\
\mu \mathrm{Sv} \mathrm{y}^{-1}\end{array}$ & $\begin{array}{c}{ }^{232} \mathrm{Th} \\
\mu \mathrm{Sv} \mathrm{y}^{-1}\end{array}$ & $\begin{array}{c}{ }^{40} \mathrm{~K} \\
\mu \mathrm{Sv} \mathrm{y}^{-1}\end{array}$ & $\begin{array}{c}\text { Total } \\
\mu S v y^{-1}\end{array}$ \\
\hline \multicolumn{6}{|c|}{ Non-Fertilized } \\
\hline T0 & 4.87 & 0.13 & 1.72 & 3.66 & 10.38 \\
\hline \multicolumn{6}{|c|}{ Fertilized } \\
\hline $\mathrm{T} 1$ & 8.230 & 0.260 & 1.72 & 5.22 & 15.43 \\
\hline $\mathrm{T} 2$ & 12.94 & 0.160 & 2.90 & 5.50 & 21.50 \\
\hline $\mathrm{T} 3$ & 5.880 & 0.110 & 1.73 & 3.42 & 11.15 \\
\hline $\mathrm{T} 4$ & 11.76 & 0.160 & 1.85 & - & 13.77 \\
\hline T5 & 1.512 & 0.130 & 1.19 & 5.06 & 7.890 \\
\hline T6 & 7.224 & 0.080 & 1.58 & 5.58 & 14.47 \\
\hline $\mathrm{T} 7$ & 12.26 & 0.210 & 1.98 & 6.08 & 20.53 \\
\hline $\mathrm{T} 8$ & 7.560 & 0.042 & 1.45 & 3.17 & 12.22 \\
\hline Average & 8.421 & 0.144 & 1.80 & 4.86 & 14.62 \\
\hline Range & $1.512-12.94$ & $0.042-0.26$ & $1.19-2.9$ & $3.17-6.08$ & $7.89-21.5$ \\
\hline Worldwide & 6.30 & 113.32 & 0.38 & 170 & 290 \\
\hline
\end{tabular}

Table (8): Excess lifetime cancer risk (ELCR) of Jew's-mallow after harvesting

\begin{tabular}{cc}
\hline Treatments & \multicolumn{2}{c}{ ELCR from Jew's-mallow $(\mathrm{Sv})$} \\
\hline \multicolumn{2}{c}{ Non-Fertilized } \\
\hline T0 & $0.036 \times 10^{-3}$ \\
\hline T1 & $0.049 \times 10^{-3}$ \\
T2 & $0.069 \times 10^{-3}$ \\
T3 & $0.036 \times 10^{-3}$ \\
T4 & $0.044 \times 10^{-3}$ \\
T5 & $0.025 \times 10^{-3}$ \\
T6 & $0.046 \times 10^{-3}$ \\
T7 & $0.066 \times 10^{-3}$ \\
T8 & $0.039 \times 10^{-3}$ \\
\hline Average & $0.0468 \times 10^{-3}$ \\
\hline Range & $0.025 \times 10^{-3}-0.069 \times 10^{-3}$ \\
\hline Worldwide & $0.29 \times 10^{-3}$
\end{tabular}




\section{Discussion}

NPK fertilizers, has an average 226Ra activity concentration, that accounted for $341.73 \mathrm{~Bq} \mathrm{~kg}-1$ in Iraq [25], and this value is lower than activity concentration values of Egypt, Germany, Brazil and USA samples, and higher than India, Nigeria, Finland and Saudi Arabia samples. This same author found also that the average $232 \mathrm{Th}$ concentration is $248.63 \mathrm{~Bq} \mathrm{~kg}-1$ which is higher than all the reported concentration from Egypt. The average $40 \mathrm{~K}$ concentration of $(5166.43 \mathrm{~Bq}$ $\mathrm{kg}-1$ ) is higher than all the reported concentration values. Results in Table (9) showed that the activity concentration of $232 \mathrm{Th}$ series $(2.47 \mathrm{~Bq}$ $\mathrm{kg}-1$ ) is very low compared to reference values in all countries, but the activity concentration of 226Ra is higher than those in India, Nigeria, Finland and Saudi Arabia and for $40 \mathrm{~K}$ is lower than all countries except Egypt.

The uptake of natural radionuclides by Jew'smallow plant of the present study incomparison with previous studies indicated that the average concentration of $40 \mathrm{~K}$ is $328 \pm 147 \mathrm{~Bq} \mathrm{~kg}-1$ reported by Gomaa et al. [34] and $171 \mathrm{~Bq} \mathrm{~kg}-1$ for $40 \mathrm{~K}$ reported by Badran et al. [7]. Jew's mallow shows a higher concentration of $40 \mathrm{~K}$ because leafy vegetables seem to absorb more potassium than other crops or the potassium are concentrated in leaves more than in any other parts of the plant. However, ranged from 8.52-16.34 Bq kg-1 for $40 \mathrm{~K}$ Table (5). In other study in Egypt for local markets in Qena, the levels of 226Ra, 210Pb, 232Th, and $40 \mathrm{~K}$ were measured by Harb[35] in some vegetables and fruits samples. The content of $226 \mathrm{Ra}, 210 \mathrm{~Pb}, 232 \mathrm{Th}$, and $40 \mathrm{~K}$ radioactivity in Jew's Mallow were $0.04 \pm 0.03,0.04 \pm 0.03$, $0.02 \pm 0.03$ and $41.46 \pm 1.55 \mathrm{~Bq} \mathrm{~kg}-1$, respectively. The TF depends on vegetation type, soil properties, climatic conditions and the type of radionuclides [5] however the TF from soil to Jew's mallow crops has been studied in many countries and found a significant difference in values [36-5-37].

\section{Conclusion}

The activity concentrations of natural radionuclide 226Ra, 238U, 232Th and $40 \mathrm{~K}$ as affected by fertilization treatments of sandy loam soil, Jew'smallow and six chemical fertilizers have been measured using high purity germanium (HPGe). These values have been compared with the worldwide reported data. The average concentrations of natural radionuclide in soil sample are below recommended level. Both the highest and the lowest values present in chemical fertilizers were found in the Jew's-mallow plant. On the other hand, the activity concentration of radionuclide in Jew's-mallow plants was higher than recommended value except $40 \mathrm{~K}$ is below. The effective dose due to ingestion of Jew's-mallow plants varied from $7.89-21.5 \mu \mathrm{Sv} y-1$ which indicated that the use of fertilizer was not effective on the level of radionuclide in Jew's-mallow plants and the possibility of developing cancer cases among individuals is neglected. In other words, the Jew's-mallow is radiological safe and be acceptable for human consumption.

Table (9): Comparison of activity concentrations of ${ }^{226} \mathrm{Ra},{ }^{232} \mathrm{Th}$ and ${ }^{40} \mathrm{~K}$ in Iraqi NPK fertilizer and other countries [25]

\begin{tabular}{ccccc}
\hline Country & ${ }^{226} \mathrm{Ra}$ & ${ }^{232} \mathrm{Th}$ & ${ }^{40} \mathrm{~K}$ & Reference \\
\hline Our study & 198.01 & 2.47 & 62.1 & Present work \\
Egypt & 366 & 67 & 4 & {$[26]$} \\
India & 79 & 28 & 1042 & {$[27]$} \\
Germany & 520 & 15 & 720 & {$[28]$} \\
Nigeria & 143 & 9 & 2729 & {$[29]$} \\
Brazil & 420 & 80 & 153 & {$[30]$} \\
Finland & 54 & 11 & 3200 & {$[31]$} \\
Saudi Arabia & 64 & 17 & 2453 & {$[32]$} \\
USA & 780 & 49 & 200 & {$[33]$} \\
Iraq & 341.73 & 248.63 & 5166.43 & {$[25]$} \\
\hline
\end{tabular}




\section{Acknowledgements}

The authors wish to express their gratitude and thanks to the Department of Radiation Protection and Civil Defense, Nuclear Research Center, Egyptian Atomic Energy Authority. Special appreciations are due to Dr. Nglaa Youssef, Dr. Rahab Hagazy and Dr. Hasan Soliman.

\section{Reference}

1-Iwaoka, K., Tabe, H. and Yonehara, H., (2013) Natural Radioactivity of Bedrock bath Instruments and Hot Spring Instruments in Japan,J. Radioanal. Nucl. Chem. 295: 817-821.

2-Hassan, N.M., (2014) Radon emanation Coefficient and its Exhalation Rate of Wasted Petroleum Samples Associated with Petroleum Industry in Egypt, J. Radioanal. Nucl. Chem. 299: 111-117.

3-Saleh, I.H., Hafez, A.F., Elanany, N.H., Motaweh, H.A. and Zaim, M.A., (2007) Radiological Study on Soils, Foodstuff and Fertilizers in the Alexandria Region, Egypt. Turkish J Eng Environ Sci 31: 9-17

4-IAEA, (1994) Handbook of Parameter Values for Prediction of Radionuclide Transfer in Temperate Environment. Technical report series no. 364 Vennia: IAEA (International Atomic Energy Agency)

5-Al-Masri, M.S., Al-Akel, B., Nashawani, A., Amin, Y., Khalifa, K.H. and Al-Ain, F., (2008) Transfer of ${ }^{40} \mathrm{~K},{ }^{238} \mathrm{U},{ }^{210} \mathrm{~Pb}$, and ${ }^{210} \mathrm{Po}$ from Soil to Plant in Various Locations in South of Syria. J Enviro Radioact 99: 322-331

6-Ramachandran, T.V. and Mishra, U.C., (1989) Measurement of Natural Radioactivity Levels in Indian Foodstuffs by Gamma Spectrometry. Appl Radiat Isot 40: 723-6.

7-Badran, H.M., Sharshar, T. and Elnimer, T., (2003) Levels of 137Cs and40K in Edible Parts of Some Vegetables Consumed in Egypt. J Environ Radioact 67: 181-90.

8-Klute, A., (1986) Methods of Soil Analysis. Part 1. Physical and Mineralogical Methods $\left(2^{\text {nd }}\right.$ edition). American Society of Agronomy Inc., Madison, Wisconsin, USA.

9-Page, A.L., (1982) Methods of Soil Analysis, Part II. Chemical and Microbiological Properties. Am. Soc. Agron., Inc. Soil Sci. Soc. Am. Inc. Madison, Wisconson, USA.

10-Dumroese, R.K., Landis, T.D. and Luna, T., (2012) Growing Native Plants in Nurseries:
Basic Concepts. Fort Collins (CO): USDA Forest Service, Rocky Mountain Research Station. General Technical Report RMRS-GTR- 274. 84 p.

11-Landis, T.D. and Wilkinson, K.M., (2014) Water Quality and Irrigation. In: Wilkinson KM, Landis TD, Haase DL, Daley BF, Dumroese RK, editors. Tropical Nursery Manual: A Guide to Starting and Operating a Nursery for Native and Traditional Plants. Washington (DC): USDA Forest Service. Agriculture Handbook 732. p 207-231.

12-Dumroese, R.K., Montville, M.E. and Pinto, J.R., (2015) Using Container Weights to Determine Irrigation Needs: A Simple Method. Native Plants Journal 16(1): 67-71.

13-Santos, E.E., Lauria, D.C., Amaral, E.C.S. and Rochedo, E.R., (2002) Daily Ingestion of ${ }^{232} \mathrm{Th}$, ${ }^{238} \mathrm{U},{ }^{226} \mathrm{Ra},{ }^{228} \mathrm{Ra}$ and ${ }^{210} \mathrm{~Pb}$ in Vegetables by Inhabitants of Rio de Janeiro City. J Environ Radioact 62: 75-86.

14-Abbady, A.G., Uosif, M.A. and El-Taher, A., (2005) Natural Radioactivity and Dose Assessment for Phosphate Rocks from Wadi ElMashash and El-Mahamid Mines, Egypt. Journal of Enviro. Radioactivity, 84, 65-78.

15-Noordijk, H., van Bergeijk, K.E., Lembrechts, J. and Frissel, M.J., (1992) Impact of Ageing and Weather Conditions on Soil-to-Plant Transfer of Radiocesium and Radiostrontium. J Environ Radioact 15:277-286.

16- Jibiri, N.N., Farai, I.P. and Alausa, S.K., (2007) Estimation of Annual Effective Dose Due to Natural Radioactive Elements in Ingestion of Foodstuffs in Tin Mining Area of Jos-Plateau, Nigeria, Journal of Environmental Radioactivity, 94, pp31-40

17-Cunha, I.I.L., Rodrigues, J.O. and Figueira, R.C.L., (1995) Assessment of Doses to the Brazilian Population from Radioactive Marine Food, In: Proceedings of an international symposium on environmental impact of radioactive releases". IAEA, Vienna, 8-12 May 1995: pp 695-697.

18-ICRP, (1994) Dose Coefficient for Intakes of Radionuclides by Workers. ICRP (International Commission on Radiological Protection) Pub. No.68. Pergamon Press, Oxford. 1994.

19-Amin, R.M. and Ahmed, F., (2013) Estimation of Annual Effective Dose to the Adult Egyptian Population Due to Natural Radioactive Elements 
in Ingestion of Spices. Pelagia Research Library Advances in Applied Science Research, 4(5), 350-354.

20-ICRP, (1991) International Commission on Radiological Protection Recommendations of the International Commission on Radiological Protection. Annals of the ICRP-60, vol. 21, pp. 13.R

21-amasamy, V., Suresh, G., Meenakshsundaram, V. and Gajendran, V., (2009) Evaluation of Natural Radionuclide content in River Sediments and Excess Lifetime Cancer Risk due to Gamma Radioactivity. Research Journal of Environmental and Earth Sciences 1(1): 6-10.

22-Alao, A.A., (2016) Determination of Excess Lifetime Cancer Risk Due to Gamma Radiation in Some Agricultural Products Obtained From Two Oil Fields in the Niger Delta Region of Nigeria. International Journal of Science and Research (IJSR), Volume 5 Issue 10, October 2016, 656 - 660

23-UNSCEAR, (2000) United Nations Scientific Committee on the Effects of Atomic Radiation. Sources, effects and risks of ionizing radiation. Report to the General Assembly with annex B. United Nations, New York.

24-Taskin, H., Karavus, M., Topuzoglu, A., Hindiroglu, S. and Karahan, G., (2009) Radionuclide Concentrations in Soil and Lifetime Cancer Risk Due to the Gamma Radioactivity in Kirklareli, Turkey. Environmental Radiation, 100, 49-53.

25-Raheem, E.H., (2015) Activity Concentration of Natural Radioactivity and Dose Assessment for Brands of Chemical Fertilizers used in Iraq. International Journal of Current Engineering and Technology, Vol.5, No.6 (Dec 2015)

26-Ahmed, N.K. and El-Arabi A.M., (2005) Natural Radioactivity in Farm Soil and Phosphate Fertilizer and Its Environmental Implication in Qena Governorate, Upper Egypt, Journal of Environmental Radioactivity, 84 (1), pp 51-64.

27-Chauhn, P., Chauhan, R.P. and Gupta, M., (2013). Estimation of Naturally Occurring in Radionuclides Fertilizers Using Gamma Spectrometry and Elemental by XRF and XRD Techniques, Microchemical Journal, 106, pp 7378 .
28-Khan, K., Khan, H.M., Tufail, M. and Shmsf, N., (1996) Gamma Spectrometric Studies of Single Super Phosphate Fertilizer Samples, In: Proceedings of National Seminar on Occupational Safety in Mining and Industries, Peshawar.

29-Jibiri, N.N. and Fasae, K.P., (2012) Activity Concentrations of 226Ra, 232Th and $40 \mathrm{~K}$ in Brands of Fertilizer Used in Nigeria, Radiation Protection Dosimetry, 148 (1), pp 132-137.

30-Saueia, C.H., Mazzilli, B.P. and Favaro, D.I.T., (2005) Natural Radioactivity in Posphogypsum and Fertilizer in Brazil, Journal of Radioanalytical and Nuclear Chemictry, 264 (2), pp 445-448.

31-Mustonen, R., (1985) Radioactivity of Fertilizer in Finland, Science of the Total Environment, 45, pp 127- 134.

32-Alharbi, W.R., (2013) Natural Radioactivity and Dose Assessment for Brands of Chemical and Organic Fertilizers Used in Saudi Arabia, J. of Modern Physics, 4 (3), pp 344-348

33-Gulmond, R.J. and Windham, S.T., (1975) Radionuclide's in the Environment, Technical Note No. ORP/CSD-75-3, USEPA, pp. 228-229.

34- Gomaa, M.A., Abdel-Fattah, A.T., Essa, M.W. and El-Shinawy, R.M.K., (1995) Radioactivity in foodstuffs in Egypt. Applied Radiation Isotope, 46, 607-608.

35-Harb, S., (2015) Natural Radiospecific activity and Annual Effective Dose in Selected Vegetables and Fruits. Journal of Nuclear and Particle Physics, 5(3), 70-73.

36-Saeed, M.A., Yusof, S.S., Hossain, I., Ahmed, R., Abdulla, H.Y., Shahid, M. and Ramli, A.T., (2012) Soil to Rice Transfer of the Natural Radionuclides in Malaysia. Rom J Phys 57(910):1417-1424

37-Poschl, M. and Nollet, L.M.L., (2007) Radionuclide Concentrations in Food and the Environment. CRC Taylor and Francis Group, New York 